Marquette University

e-Publications@Marquette

Marketing Faculty Research and Publications

Business Administration, College of

$1-1-2016$

Poverty, Prosperity and the Challenges of the Good Company

Michael John Naughton

Marquette University

Nicholas J. C. Santos

Marquette University, nicholas.santos@marquette.edu

Accepted version. Journal of Catholic Social Thought, Vol. 13, No. 1 (Winter 2016): 3-15. DOI. (C) 2016 Philosophy Documentation Center. Used with permission. 


\title{
Poverty, Prosperity and the Challenges of the Good Company
}

\author{
Michael Naughton \\ Center for Catholic Studies, University of St. Thomas \\ St. Paul, MN \\ Nicholas Santos \\ Marketing Department, Marquette University \\ Milwaukee, WI
}

\section{Introduction}

The articles in this volume originate from papers delivered at the 9th International Conference on Catholic Social Thought and Management Education at De La Salle and Ateneo Universities in Manila, Philippines (February 26-28, 2015). ${ }^{1}$ The theme of the conference was "Poverty, Prosperity and the Purpose of Business" within the Catholic social tradition. In attendance were approximately 300 participants representing 22 countries from 80 Catholic colleges and universities. They came from disciplines in management, philosophy, finance, accounting, theology, marketing, economics, and others. There were also leaders from business, many of whom were 
from the Philippines, who brought their experiences to bear on the conversations. Along with this diversity of education and experience were people of different faith traditions whose moral and spiritual commitments run deep on the importance of mission and identity of Catholic universities.

Some fruits of the conference are shared in this volume, where scholars examine the current situation of poverty and inequality in the world and the role of business, engaging the intellectual, moral, and spiritual resources of the Catholic social tradition in relationship with other philosophical and religious traditions. The papers provide theoretical and practical examinations drawing upon an interdisciplinary exploration of the humanities, social sciences, and business disciplines to develop creative and insightful ways to address the multi-faceted challenges of prosperity and poverty for business. A unique contribution of this volume that came from having the conference in Manila is the contribution from Filipino scholars. In particular, the work of Liberatore, Cleofas, and Bautista et al. provide powerful insights from Filipino culture and practice in relation to Catholic social thought and business and economic life.

The topic and timing of the conference were rather appropriate for multiple reasons. The Millennium Project, which was commissioned in 2002 by the United Nations to develop a plan for reaching poverty reduction goals, had 2015 as its target date. The year 2015 also marked the anniversary of two very important documents for Catholic higher education: Gaudium et spes (1965-50 years) and Ex corde ecclesiae (1990-25 years). These two documents served as an important backdrop to our conference since they uphold the fundamental role that Catholic universities play in analyzing the problems and solutions of poverty, particularly those related to business as a key wealth generating and distributing institution.

Gaudium et spes, as its more descriptive title indicates, "Church in the Modern World," famously begins with the following words: "The joys and the hopes, the griefs and the anxieties of the men of this age, especially those who are poor or in any way afflicted, these are the joys and hopes, the griefs and anxieties of the followers of Christ. Indeed, nothing genuinely human fails to raise an echo in their 
hearts." 2 The document opens by exposing the great panorama of the pain and suffering of the poor, the underdevelopment of which the majority of people live, and the horizon of joy and hope, particularly because "progress in the methods of production and in the exchange of goods and services has made the economy an instrument capable of better meeting the intensified needs of the human family." ${ }^{3}$ Yet, the document goes on to state that "at the very time when the development of economic life could mitigate social inequalities, ... it is often made to embitter them; or, in some places, it even results in a decline of the social status of the underprivileged and in contempt for the poor. ${ }^{\prime 4}$ What Gaudium et spes and the whole of the Catholic social tradition brings to the conversation is an appeal for the common good and an examination of whether human work and in particular business really upholds or transgresses human dignity.

For its part, Ex corde ecclesiae, the "magna carta" for the Catholic university, calls it "to become an ever more effective instrument of cultural progress for individuals as well as for society. ${ }^{5}$ A Catholic university's research as well as curricular activities should focus on the "serious contemporary problems in areas such as the dignity of human life, the promotion of justice for all, the quality of personal and family life, the protection of nature, the search for peace and political stability, a more just sharing in the world's resources, and a new economic and political order that will better serve the human community at a national and international level." ${ }^{\prime 6}$ In this sense, "the Christian spirit of service to others for the promotion of social justice is of particular importance for each Catholic University" and adds that the Gospel is an urgent call to promote "the development of those peoples who are striving to escape from hunger, misery, endemic diseases and ignorance; of those who are looking for a wider share in the benefits of civilization and a more active improvement of their human qualities; of those who are aiming purposefully at their complete fulfillment."

Besides drawing upon these two documents, the conference also used the Pontifical Council for Justice and Peace's Vocation of the Business Leader (VBL) to more specifically frame the issues by defining the good business does in light of three essential goods: 
NOT THE PUBLISHED VERSION; this is the author's final, peer-reviewed manuscript. The published version may be accessed by following the link in the citation at the bottom of the page.

- Good Goods: making goods which are truly good and services which truly serve;

- Good Work: organizing work where employees develop their gifts and talents; and

- Good Wealth: creating sustainable wealth and distributing it justly.

When businesses properly order these three goods well, they make an irreplaceable contribution to the prosperity of humankind, a prosperity that includes not only material wealth but also spiritual and moral welfare (see Liberatore's essay on the importance of defining institutional goods). Without a vibrant business and an entrepreneurial sector, goods and services languish, work and the talents of people are not utilized, and wealth is scarce. When businesses do not foster these three goods, they create significant inequity, and in particular exclusion. Without a panoramic moral and spiritual lens, business and the market fail to promote prosperity by ignoring or exploiting goods and services for the poor, providing dehumanizing work, and failing to create and distribute wealth justly.

These three goods, which begin to describe the good business does, are not easy goods to achieve for multiple reasons. As an introduction to this volume, we highlight some of these challenges, which will provide an overall flavor of the contributions of this volume as well as the larger conference we had in Manila. We will then proceed to provide a summary of each of the papers in this volume.

\section{Challenges of the Good Company}

Good Goods and the Challenge of Consumerism: One of the principal questions for business is what criteria inform how one determines the "good" of products and services. If one is left only with economic categories, the default answer is the market, which takes on a logic of its own. Within this logic, "goods and services" are viewed as objects or actions that have market value. That is, they are "valued" by the market in the sense that persons or groups are willing to exchange money for them. If nobody will buy the goods, then their market value is zero (at that time), but if people do buy them, then value is instantly placed on them. ${ }^{8}$ 
What lies behind this market view of goods are several assumptions that define "consumerism" (see Laczniak, Santos, and Klein's article for more details). The first assumption is that "price" determines value. Value is not reliant on the content or the "goodness" of the product, but on how much people will pay for it. The other assumption is that the more choices we have as consumers, the more "free" we are. Hence, the market is "good" to the extent of one's variety in choosing products and services. It is on this logic of the market that a whole set of legal products and services are justified, such as tobacco and especially the way it is marketed, exam cheat websites, rent-to-own services with exorbitant interest rates, pornography, highly speculative activities, violent video games, all sorts of weapons, pirating music sites, so-called gentleman clubs, gambling, and so forth.

The CEO of the former company RJR Nabisco (which produced cigarettes as well as food), Steven Goldstone, argued that the production of tobacco is a virtuous profession because it increases people's choices. ${ }^{9}$ His responsibility as a CEO is not to dictate which choice one should make (since this would be restricting another's freedom), but rather, to provide consumers with the option of whether to smoke or not. The "choice" of consumers dictates whether goods or services are produced; no moral criteria on the part of producers is allowed to intrude on the freedom of choice of the consumer, otherwise the firm would be accused of the vice of paternalism.

Within the Catholic social tradition as well as other moral traditions, the authentic value of goods and services is not determined only by "what the market will bear" in terms of price. The market and its price mechanism are necessary but insufficient criteria to determine good goods. The authentic value of goods and services depends upon the centrality of those goods and services to the wellbeing of the customer and the greater good of the community. While this is not always clear at any particular time, reducing good goods to the market only creates a moral and spiritual poverty that blunts the human conscience and where "there is no longer room for others, no place for the poor."10 The good of human activity if it is to take root and develop needs to be grounded and connected to the truth about our 
surroundings and the nature of the person. If we allow consumerism to taint that reality, we actually become more impoverished due to the failure to see and remember our worth and the worth of others.

Good Work and the Challenge of Utilitarianism: At the heart of good work is not a utility, but a person, which is why the Catholic social tradition speaks about the "subjective dimension" of work. The worker, the subject of work, is also affected and changed. It is precisely because of this subjective dimension that the virtues, those good habits whereby people become good, are so important to good work (see Saxton's paper for more details). The issue is not a question of whether if, but how a person changes; and the key to understanding the significant revealing of his or her personhood is not found in the amount of revenues generated, or levels of promotions, or the percentage of market share captured, but rather, in the responsible relationships he or she has forged with others in the actions of operating the business. The purpose of a business is never only to make money, or produce a product or service, but to accomplish these goals in such a manner where the businessperson and those he or she works with develop as persons.

While there are many challenges to good work, the utilitarian mindset that reduces work to only a form of instrumental rationality spurs and spreads a moral and spiritual poverty at work. Because of its competitive and economic character and fundamental need to change the objective order, business is prone to succumbing to the forces of a utilitarian ideology that disorders and undermines good work. Although utility and instrumental calculations are an irreplaceable function of business, it is precisely that-a function, a means to be used-not a philosophy or end that defines one's work (see Zamagni's paper).

Work, informed by utilitarianism, is viewed as bargained-for, voluntary exchanges or transactions. Thus, a business is seen simply as a nexus of discrete human actions, described as transactions or exchanges, with costs and benefits associated with them. ${ }^{11}$ The utilitarian logic orders these exchanges with the goal of maximizing the utility satisfaction, which is largely defined in terms of the economic value to the firm. What is often left out of the picture is the 
kind of relationships that come from them, much less those that precede or sustain them. Virtue, character, and community are marginal realities that do not fit within such a lexicon of business and governance, even though, without them-think here of trust, a true cost reducer-the leadership and governance of a business would be prohibitively expensive or even impossible (see Dierksmeier and Sison's essay).

The fundamental insight of the subjective dimension of work and its relationship to virtue that is at the heart of the Catholic social tradition replaces a utilitarian outlook with a "personalism" that lies at the center of good work and includes the notion of moral and spiritual poverty and prosperity (see McNerney and Bautista et al.'s papers). Good work, then, fosters a community of persons that presents employees with opportunities to exercise personal initiative and to overcome the spiritual poverty of disengagement. When leaders take upon themselves to trust lower level decisions, they are conferring a significant authority upon employees. By taking on the risk of another's decision, delegation, as a "technique of management," moves to delegation as part of the virtue of trust, strengthening relationships. The Catholic social tradition calls this "subsidiarity," which is an important principle in defining good work. ${ }^{12}$ While there will always be an instrumental character to this work, more can be said of good work, namely the fostering of trust-filled relationships among team members in the work to be done.

Good Wealth and the Challenge of Moral Relativism: When consumerism and utilitarianism are the principal systems informing the relationships of employees and consumers, the logic of the market dominates business, leaving it with a strange hybrid of moral relativism on the one hand and market absolutism on the other. From a relativistic perspective, "all moral judgments are nothing but expressions of preference, expressions of attitude or feeling."13 Ironically, however, this moral relativistic position creates a market absolutism by price, and in particular shareholder wealth, the only real form of wealth within a business. Thus, any objective claim of what is "good" is replaced with value understood as price, and the only legitimate goal within business then is maximizing material, and in particular shareholder, wealth. ${ }^{14}$ The free market absolutism, which is 
supported by a moral relativism, argues that the attainment of moral goods within the organization is inaccessible, since "one man's good is another's evil." 15 As a result, managers tend to avoid engaging in any moral debate over the good of the business and instead, enter the discussion as technicians whose principal focus is measurable by economic value. ${ }^{16}$

This strange but rather common hybrid of moral relativism and market absolutism shows its moral poverty when it comes to profit, an important source of wealth. When the profit of a firm becomes its dominant purpose, alienation seeps in because there has been a "reversal of means and ends."17 Profit is a means, not an end, and when it becomes the principal motive of shareholders and leaders of the firm, workers begin to adopt a similar motive-wage maximization. This erodes the possibility of deeper bonds of communion since profit and wages do not by themselves have the capacity to bind people together in a way that enables them to flourish-they can only be allocated and not participated in to provide real relationships. The challenge of moral relativism and market absolutism poses a particular threat to aspiring businesspersons, due to the reconstruction of the meaning of wealth as only material. There are few lessons in business more powerful for students to learn than to see that profit and wealth are good servants, but they are lousy and destructive masters.

The other significant challenge that needs to be raised in light of the theme of this volume is the inability of a market logic to detail a rich and robust understanding of good wealth, especially in the relationship between its creating and distributing function. You cannot distribute wealth you have not created, but neither can you create good wealth without justly distributing it to those who are responsible for its creation. These two dimensions of good wealth, creation and distribution, which are too often juxtaposed to each other, cannot be understood without stitching together the fabric that holds the two together. ${ }^{18}$ Any society that seeks to mitigate poverty will have to both foster wealth-creating capacities and improve upon how this growth can be more justly shared.

In terms of wealth creation, business enterprises are the economic engine of society. As a creator of good goods and good 
work, business must exercise the stewardship of resources in a way that it creates more than what it has been given. A business with a healthy balance sheet, for example, simply has greater abilities to build a future than those laden with debt. Wealth creation, however, brings with it the concomitant task of wealth distribution. The principle of just distribution calls for wealth to be allocated in a way that creates "right relationships" with those who have participated in the creation of such wealth. This principle raises a set of knotty and enduring moral challenges for business (see Zamagni's paper on the problems of inequality and wealth distribution). Among other things, businesses need to discern and account for the moral implications of how they make a just distribution of this wealth to employees (a just wage as well as possibilities of employee ownership), customers ( just prices), owners (just returns and access), suppliers (just prices and fair terms on receivables), government (just tax payments), and the larger community and especially the poor (philanthropy).19 Inherent within the very nature and purpose of business is a just distribution of wealth, which creates authentic prosperity and alleviates debilitating poverty (see Cleofas' essay on attitudes of the poor and distribution among Filipino business leaders).

\section{Summary of this Volume}

While the three goods of business are articulated throughout this volume, most of the authors did not organize their papers according to these three goods, although they all discuss the goods in one form or another. Because of this, we provide a summary of each of the papers on their own terms.

Stefano Zamagni's essay is the longest and most comprehensive essay of this volume. He addresses the problem of poverty and the global economy both by dealing with macro economic and political dimensions of the problem as well as addressing specific dimensions for business and especially entrepreneurship. Critical of the prevailing libertarian arguments for a free trade market based approach, Zamagni argues that such an approach cannot by itself address the problems of market instability, increasing inequality, and the inability to understand the multiple aspects of poverty as well as prosperity (material, social/relational, and spiritual). He also recognizes the 
important role that business and entrepreneurship play in generating civic culture that is necessary to produce goods for the larger society. At the heart of civic culture is the virtue of gratuitousness that informs those actors within a business of the intrinsic character of relationships and the goods that can come from these relationships. Without this virtue, "the business itself will implode, because the good that gratuitousness brings (passions, ideals, values, etc.) is the place where the market, wealth, and profit are regenerated." But gratuitousness cannot be generated by the economy alone. It is dependent upon the larger culture and in particular the family, church, education, volunteer organizations, and so forth. He concludes his essay reminding us that culture cannot be taken for granted.

On a related note, Michael Liberatore invites us to rediscover virtue through community and communal life rather than merely through individual agency. Liberatore is critical of the Capabilities Approach put forward by the Noble laureate, Amartya Sen, whose libertarian perspective focuses on individual choices and does not sufficiently consider the communal reality that informs those choices. Liberatore argues that the capabilities approach needs to be augmented with a communitarian orientation that recognizes that people do not just exercise capabilities but also shape those capabilities through the very structures they are part of. The Filipino concept of "kapwa," which refers to a shared inner self and one that is consistent with the communitarian approach of Catholic social teaching, is presented as a lens through which "justice rooted in shared communal identities may be developed."

Utilizing the three goods framework of the Pontifical Council for Justice and Peace's Vocation of the Business Leader (VBL), Gene Laczniak, Nicholas Santos, SJ, and Thomas Klein provide a clear articulation of the nature and role of business in serving the common good via the production and distribution of goods and services. As marketing professors, they relate the "good goods" discussion in the VBL to the discipline of marketing, examining in more detail what exactly is a "good good" within business. While some products and services have clear good and bad connotations, many goods are deemed good based on the use of product (value-in-use), how it is marketed, distributed, priced, and so forth-all of which are issues 
addressed in marketing. What the authors provide is a helpful engagement of the VBL and the discipline of marketing, pointing out places of synthesis between the two. More specifically, they propose a framework called the "Integrative Justice Model" (IJM) that is consistent with the VBL and the Catholic social tradition and that provides guidance for companies to provide products and services that truly lift up disadvantaged populations and help create and maintain sustainable economic communities.

Drawing specifically from Evangelii Gaudium and Caritas in Veritate, Claus Dierksmeier and Alejo Sison insightfully point out that the Catholic social tradition, unlike certain forms of capitalism and communism, does not see the economy as an outcome of quasi natural forces, but rather, as the etymology of the word indicates, the economy is about the "management of the household," which includes moral and ethical criteria. Key to this management of the household is addressing the challenges of deprivation and exclusion within the economy. Addressing these problems includes the full force of the political, economic, and cultural dimensions of society. The authors prefer using the terms "deprivation" and "exclusion" instead of poverty and inequality. They explain that "[w]hile poverty can even be a virtue, and inequality a fact of life, both deprivation and exclusion are always moral evils." Examining these distinctions within the economic happiness literature, they utilize humanistic management literature in relation to Catholic social thought, which they believe improves upon conventional business responses to deprivation and exclusionary problems within business.

Jacklyn Cleofas argues against the situationist challenge to virtue ethics. Situationists hold that virtue or character is not robust or reliable in producing morally desirable behaviors because of the focus on the individual. Cleofas suggests that instead of abandoning virtue, there should be a greater appreciation for the relationality of virtue in terms of the varied forms of interpersonal processes. Then, "thinking about the traits of those who are poor or prosperous no longer goes against recognizing the situtational determinants of poverty." Such a mindset allows one to consider socio-cultural structures, social relationships, and norms that make virtuous behavior possible. 
Brian Saxton grapples with the "good work" component of the good company. While Catholic social teachings calls on business owners to invest in the intellectual and spiritual development of their employees, firms are less likely to make such investments if they are unable to capture much value from it. Saxton proposes that instead of investing in the development of individual employees, firms should invest in enhancing relationships among employees that enable them to function better as a unit. Such an approach not only helps the subjective human flourishing of the individual employees but also creates competitive advantage for the firm via better organizational performance.

Fr. John McNerney warns of the "anthropological anorexia" that too often plagues our understanding of the economy and business. Principles of human economic action that "are fundamentally 'personcentric'" are needed to strengthen economics and business. He argues that these personalist principles were weakened from the time of Adam Smith onward. He believes that the Austrian economic tradition with its emphasis on a thoroughgoing analysis of "human action" is one source of recovery. He also discusses the important role of the Catholic social tradition and in particular one concrete expression of that tradition found in the case of Foxford Woolen Mills in County Mayo, Ireland. The case "x-rays" this personalism through penetrating the meaning of human action. Founded by Sr. Agnes Morrogh-Bernard (Mother Mary Arsenius) in the aftermath of the potato famine and way before the term "social entrepreneurship" was coined, Foxford Woolen Mills was seen as an essential piece to addressing not only the material but also the spiritual poverty stricken area of Western Ireland. She and her order of the Sisters of Charity recognized that philanthropic handouts would not address the deeper spiritual poverty of the area, which, because of the material deprivation, repressed entrepreneurial virtues such as creativity, industriousness, and courage.

Reynaldo Bautista, Johnny Amora, Raymond Charles Anicete, Beni Alfred Estepa, and Ferdinand Alversado conducted an empirical study to assess the effectiveness of Fair Trade certification in ameliorating the lives of small producers. In effect they look at different dimensions of social capital such as: groups and networks; 
trust and solidarity; collective action; information and communication; social cohesion and inclusion; empowerment and political action; and economic performance; and study their relationship with subjective wellbeing and quality of life. Further, they investigate whether Fair Trade acts as a moderating variable between social capital and subjective wellbeing and quality of life. Their study finds that only empowerment/political action and economic performance have a significant relationship to wellbeing and quality of life. Additionally, they also find that the effects of the social capital dimensions on wellbeing and quality of life are the same whether they have Fair Trade certification or not.

\section{Conclusion}

Our hope for this issue is that Catholic universities around the globe, and especially their business programs, will take up their vocation to both engage the significant human issues of poverty and prosperity as well as draw upon the Catholic social tradition. This relationship will help Catholic universities and their businesses schools to be more consciously mission driven. This will not be an easy task. As the Principles of Responsible Management Education (PRME) Report Fighting Poverty through Management Education indicates, the topics of "poverty and inequality ranked next to last out of 14 responsible management topics for undergraduates." 20 While there are multiple reasons for this lack of engagement-overcrowded curriculum, distorted incentives, functional specialization, lack of interest by students, quantitative dominant research, and so forth- poverty related issues will struggle to find a place in business education without a more robust mission driven rationale.

A Catholic university has a mature and significant social tradition from which to draw. As we have articulated in this introduction, business is not a uni-dimensional reality of profit maximization, but rather a multidimensional activity that entails good goods, good work, and good wealth. When business is simply reduced to "wealth maximization for shareholders" (largely a restricted notion of what we mean by good wealth), it creates an "economy of exclusion" as well as moral and spiritual alienation among business leaders. ${ }^{21}$ One of the challenges of modern culture is the "thinning out"

Journal of Catholic Social Thought, Vol 13, No. 1 (Winter 2016): pg. 3-15. DOI. This article is (C Philosophy Documentation Center and permission has been granted for this version to appear in e-Publications@Marquette. Philosophy Documentation Center does not grant permission for this article to be further copied/distributed or hosted elsewhere without the express permission from Philosophy Documentation Center. 
of institutions, reducing them from a vibrant set of integrated goods to one flat good-universities to career credentialing, religion to emotive experience, marriage to a legal contract between autonomous individuals, and business to shareholder wealth maximization. This reductionism deprives institutions of a transcendent breathing space resulting in a moral and spiritual desert, where all motives are selfinterested, all knowledge is empirical and all rationality is instrumental. Our hope is that this volume is one modest step in the move of articulating mission driven business education for Catholic universities.

Finally, we are particularly grateful to Kelsey Wanless, who helped in editing the papers, Mary Kay O'Rourke who managed the process, and the generous contributions of Ateneo de Manila University, De La Salle University, De La Salle-College of Saint Benilde, Marquette University, Saint John's University, the University of St. Thomas, and an anonymous donor.

\section{Notes}

${ }^{1}$ To view the papers from the conference visit $<$ http://www.stthomas.edu/cathstudies/cst/research/conferences/man ila/>.

${ }^{2}$ Gaudium et spes (1965), §1.

${ }^{3}$ Ibid, §63.

${ }^{4}$ Ibid, $\S 63$.

5John Paul II, Ex corde ecclesiae (1990), §32.

${ }^{6}$ Ibid, §32.

${ }^{7}$ Ibid, §34.

${ }^{8}$ See Kenneth Goodpaster, "Goods that are truly good, and services that truly serve," in Journal of Business Ethics 100, no. 1 (2011): 9-16.

${ }^{9}$ Taken from an interview from The News Hour with Jim Lehrer, January 29, 1998, available at <https://archive.org/details/tobacco_ovy27a00>.

${ }^{10}$ Francis, Evangelli gaudium, §2.

${ }^{11}$ See Michael C. Jensen and William Meckling, "Theory of the Firm: Managerial Behavior, Agency Costs, and Ownership Structure," in Journal of Financial Economics 3 (1976): 305-60. Oliver E. Williamson, Markets and Hierarchies: Analysis and Antitrust Implications (New York: Free Press, 1975). 
NOT THE PUBLISHED VERSION; this is the author's final, peer-reviewed manuscript. The published version may be accessed by following the link in the citation at the bottom of the page.

${ }^{12}$ See Michael Naughton, Jeanne Buckeye, Kenneth Goodpaster, and Dean Maines, Respect in Action: Applying Subsidiarity in Business (St. Paul: University of St. Thomas, 2015), www.stthomas.edu/ria.

${ }^{13}$ Alasdair MacIntyre, After Virtue (Notre Dame: University of Notre Dame Press, 2007), 12.

${ }^{14}$ While we often associate "wealth" with material goods, the very etymology of the word derives from the old English "welde," meaning "wellbeing," particularly moral and spiritual wellbeing, "often in the testamentary phrase for the wealth of (one's) soul" (see The Compact Edition of the Oxford English Dictionary, 1982, s.v. "wealth"). Wealth consists most fundamentally in the quality of one's relationships to those with whom relation is given constitutively, in the act of creation: God, family, neighbor, citizen, and all the creatures of nature. It is the deprivation of these relationships, which creates a meaninglessness equated to the deepest form of poverty.

${ }^{15}$ See Milton Friedman, "The Social Responsibility of Business is to Increase its Profits," New York Times Magazine (September 13, 1970), 32-33, 122, 124, 126. In Milton Friedman's response to John Paul II's Centesimus annus, he confesses "that one high-minded sentiment, passed off as if it were a self-evident proposition, sent shivers down my back: -obedience to the truth about God and man is the first condition of freedom. Whose - truth? Decided by whom? Echoes of the Spanish Inquisition?" For Friedman and many others, business is largely an economic and legal reality where the moral and spiritual dimensions of life are principally private and individual.

${ }^{16}$ While many businesses speak of "values," this way of speaking of the good poses particular challenges. Don Briel pointed out to us in a conversation that once you shift to the language of values, one loses inevitably the languages of being, beauty, and truth. Values are private but I have the right to demand that you not only respect my private values but also the legal right to secure them. Unfortunately, even churches have fallen into the trap of speaking about Christian values implying arbitrarily held beliefs, rather than speaking about truths inscribed on the heart and mind. Briel directed us to an interview with Ivan Illich where the interviewer David Cayley explained that "the language of values was the language of Nietzsche, the language in which individuals willed the meaning of their own existence after the death of God." Illich responded: "It is a generalization of economics. It says, this is a value, this is a nonvalue, make a decision between the two of them. These are three different values, put them in a precise order. But when we speak about the good, we show a totally different appreciation of what is before us. The good is convertible with being, convertible with the beautiful,

Journal of Catholic Social Thought, Vol 13, No. 1 (Winter 2016): pg. 3-15. DOI. This article is (C Philosophy Documentation Center and permission has been granted for this version to appear in e-Publications@Marquette. Philosophy Documentation Center does not grant permission for this article to be further copied/distributed or hosted elsewhere without the express permission from Philosophy Documentation Center. 
NOT THE PUBLISHED VERSION; this is the author's final, peer-reviewed manuscript. The published version may be accessed by following the link in the citation at the bottom of the page.

convertible with the true. For me, the discussion of values is sadly subjective, sadly detached from nature" (See David Cayley, Ivan Illich in Conversation [Toronto: House of Anansi Press, 2007], 160-61).

${ }^{17}$ John Paul II, Centesimus annus, §41.

${ }^{18}$ On distinguishing good and bad wealth, see Charles Clark, "Promoting GoodWealth: CST and the Link between Wealth, Well-Being and Poverty Alleviation," accessed April 8, 2015, <http://www.stthomas.edu/media/catholicstudies/center/johnaryanins titute/conferences/2015-manila/ClarkBackgroundFinal.pdf $>$.

${ }^{19}$ Pontifical Council for Justice and Peace, Compendium of the Social Doctrine of the Church, 171-81. See also the US Bishops Pastoral Letter, "From Economic Justice for All" (1986), 74-75, accessed April 8, 2015, http://www.usccb.org/upload/economic_justice_for_all.pdf.

${ }^{20}$ See PRME's Report on Fighting Poverty through Management Education: Challenges, Opportunities, Solutions, 16-17, $<$ http://www.unprme.org/resourcedocs/FightingPovertythroughManagementEducationChallengesOpportu nitiesandSolutions.pdf $>$. However, the Aspen Institute released a report in 2007 indicating that the number of business schools that include material focused on BoP grew substantially in 2007 compared to 2005 (Aspen Institute, "A closer look at business education: Bottom of the Pyramid," June 2007, accessed July 19, 2007, <http://www. beyondgreypinstripes.org/pdf/BOP.pdf>).

${ }^{21}$ See Francis, Evangelii gaudium, §53.

Journal of Catholic Social Thought, Vol 13, No. 1 (Winter 2016): pg. 3-15. DOI. This article is @ Philosophy Documentation Center and permission has been granted for this version to appear in e-Publications@Marquette. Philosophy Documentation Center does not grant permission for this article to be further copied/distributed or hosted elsewhere without the express permission from Philosophy Documentation Center. 